\title{
Enzyme technology in Brazil: trade balance and research community
}

\author{
Karina de Godoy Daiha' ${ }^{1}$ Gabriela Coelho Brêda' ${ }^{1}$, Ariane Leites Larentis², Denise Maria Guimarães Freire ${ }^{3}$ \\ and Rodrigo Volcan Almeida ${ }^{*}$
}

*Correspondence:
volcan@iq.ufrj.br
${ }^{1}$ Laboratório de
Microbiologia Molecular
e Proteínas, Instituto de
Química, Universidade
Federal do Rio de Janeiro,
Ave Athos da Silveira
Ramos, 149, Ilha da
Cidade Universitária,
Centro de Tecnologia,
Block A, Room 541, Rio de
Janeiro $21941-909$, Brazil
Full list of author information
is available at the end of the
article

*Correspondence:

volcan@iq.ufrj.b

Química, Universidade

Federal do Rio de Janeiro,

Ave Athos da Silveira

Ramos, 149, llha da

Full list of author information article

\begin{abstract}
Despite Brazil's large numbers and its position as one of the world's ten largest economies, its exports are mainly composed of non-industrial or low-technological goods. It results in a trade deficit and technological dependence that affects several sectors, including biotechnology. The present study aims at analyzing the Brazilian trade balance (from 1996 to 2013) of enzyme-related goods and correlating such data with the scientific community, number of scientific publications and filings of patent applications related to four technological areas that commonly use lipases, the most important enzyme studied in Brazil. Brazil seems to have a sufficient, but not saturated, technical staff working in enzyme-correlated areas, while the trade balance is deteriorating over the years. The major problem seems to be that the increase in the number of scientists is not accompanied by a proportional increase in effective development policies. These conclusions are corroborated by the number of scientific publications and patent documents related to the industrial use of lipases, one of the most important enzyme group: while Brazil has an important contribution in publishing scientific documents regarding the industrial use of lipases, its contribution in filing patent applications is only marginal.
\end{abstract}

Keywords: Enzyme technology, Trade balance, Research community, Brazil

\section{Background}

Brazil is a country of large numbers: it is a continental size country, the fifth most populous country in the world (United Nations Population Found 2010) and one of the world's richest countries in biodiversity terms (Mittermeier et al. 2005). Brazil occupied the seventh position in the ranking of world's largest economies in 2013 (Centre for Economics and Business Research 2013). Despite of the above, Brazil's exports are mainly composed of non-industrial or low-technological goods. In 2010, the commodities accounted for $51 \%$ of Brazil's exports, representing around $5 \%$ of all commodities traded in the world. In parallel, Brazil's contribution to the global exportation of high-technological goods was of around $0.5 \%$ in the same period (Em discussão! Revista de Audiências Públicas do Senado Federal 2012).

Besides affecting the Brazilian trade balance, this scenario causes a high technological dependence that reaches several areas, including the biotechnology sector. Even though the significant growth of this sector in Brazil is worldwide recognized (Nature Editorial

(c) 2016 The Author(s). This article is distributed under the terms of the Creative Commons Attribution 4.0 International License (http://creativecommons.org/licenses/by/4.0/), which permits unrestricted use, distribution, and reproduction in any medium, provided you give appropriate credit to the original author(s) and the source, provide a link to the Creative Commons license, and indicate if changes were made. 
2010; Resende 2012), studies involving Brazilian biotech companies showed that $86 \%$ of them depend on imported goods and services (BRBiotec Brazil 2011). Enzyme technology is a subfield of biotechnology where new processes have been and are being developed to manufacture both bulk and high added-value products utilizing enzymes as biocatalysts. Food, fine chemicals, pharmaceuticals and biofuels are examples of products manufactured using enzymes. This kind of catalyst are also used to provide services, as in washing and environmental processes, or for analytical and diagnostic purposes (Buchholz et al. 2012).

Enzymes are an important branch of biotechnology market, and the world demand on several enzymes is expected to rise $6.3 \%$ annually to U\$7 billion in 2017, with Latin America being responsible for a significant percentage of such consumption (Freedonia Group 2014). Considering the rising economic importance of enzyme technology, the present article analyzes the Brazilian trade balance of enzyme-related goods and discusses such data in terms of the Brazilian scientific community, which discussion is further corroborated with bibliometric studies, aiming at answering the following questions: If Brazil's biotechnological potential is high, why is the enzyme market so in deficit? Has Brazil enough technical staff for developing enzyme technologies?

\section{Methods}

\section{Trade balance}

Data from 1996 to 2013 have been collected from AliceWeb, a public online database developed by the Brazilian Ministry of Development, Industry and Foreign Trade (MDIC). All data related to imported and exported goods are classified in accordance with the Mercosur Common Nomenclature $(\mathrm{MCN})$, which was adopted by Brazil, Argentina, Paraguay and Uruguay in 1995. The MCN codes comprise eight digits, the first six being formed by the Harmonized System (an international standardized system of names and numbers to classify traded goods) and the last two being specific to the Mercosur context. Thirty-one MCN codes have been selected as being directed to an enzyme itself or an enzyme-containing product. Three of them (30029010, 38220010 and 38220090) have an unclear description and were partially included in the present study as they may encompass enzyme-containing products. The selected MCN codes are listed in Table 1.

\section{Research}

Statistic analyses on the number of master's and doctoral degrees granted by December 2013 in Brazil were made based on data obtained at the National Council for Scientific and Technological Development (CNPq) website (www.cnpq.br). Information on the number of researches involved in areas related to enzyme technology and their scientific production were collected at the same website, by searching for keywords in the researchers' online curriculum (lattes.cnpq.br).

\section{Bibliometric studies}

Searches for scientific publications and patent documents from 1983 to 2012 were performed respectively using the platforms Web of Science and Orbit.com. The searches were carried out to four important industrial sectors that employ lipases-kinetic 
Table 1 Mercosur Common Nomenclature (MCN) codes and their respective description

\begin{tabular}{|c|c|}
\hline MCN codes & Products \\
\hline 23099060 & Preparations with xylanase and Beta-Glucanase, supplemented with wheat bran \\
\hline 30021032 & Plasmin (Fibrolysin) \\
\hline 30021033 & Urokinase \\
\hline 30029010 & Diagnostic reagents of microbial origin ${ }^{\mathrm{a}}$ \\
\hline 30039021 & Drug containing streptokinase, except in doses \\
\hline 30039022 & Drug containing L-asparaginase, except in doses \\
\hline 30039023 & Drug containing deoxyribonuclease, except in doses \\
\hline 30039029 & Drugs with other enzymes, without vitamins, etc., except in doses \\
\hline 30049011 & Drug containing Streptokinase, in doses \\
\hline 30049012 & Drug containing L-asparaginase, in doses \\
\hline 30049013 & Drug containing deoxyribonuclease, in doses \\
\hline 30049019 & Drug containing other enzymes in doses \\
\hline 32029030 & Enzymatic preparations for pre-tanning \\
\hline 35071000 & Rennet and its concentrates \\
\hline 35079011 & Alfa-amylase (Aspergillusoryzae) \\
\hline 35079019 & Other amylases and their concentrates \\
\hline 35079021 & Fibrinucleases \\
\hline 35079022 & Bromelain \\
\hline 35079023 & Streptokinase \\
\hline 35079024 & Streptodornase \\
\hline 35079025 & Mixture of streptokinase and streptodornase \\
\hline 35079026 & Papain \\
\hline 35079029 & Other proteases and their concentrates \\
\hline 35079031 & Lysozymeand its hydrochloride \\
\hline 35079032 & L-asparaginase \\
\hline 35079039 & Other enzymes and their concentrates \\
\hline 35079041 & Cellulase-based enzymes \\
\hline 35079042 & Transglutaminase-based enzymes \\
\hline 35079049 & Other prepared enzymes \\
\hline 38220010 & Reagents for determination of blood or urine composition, paper support, etc. ${ }^{a}$ \\
\hline 38220090 & Other diagnostic or laboratory reagents ${ }^{\mathrm{a}}$ \\
\hline
\end{tabular}

a MCNs which descriptions are unclear regarding the inclusion of enzyme-containing products

resolution, production of detergents, food and feed and biodiesel-using the search strategies disclosed in Tables 2 and 3.

The data obtained from these searches also resulted in a study that aimed at evaluating the biotechnological interest towards lipases, which study was published by our research group in the journal Plos One, in 2015 (Daiha et al. 2015).

\section{Results and discussion}

\section{Trade balance}

The evolution of Brazilian trade balance in the enzyme technology field has been analyzed in terms of the value and volume of the goods imported and exported by the country. In both cases, it is verified a growing trade deficit through the period of analysis, which profile may be related to the fact that Brazil's imports are increasing at a significant higher rate when compared to the exports (Fig. 1). 
Table 2 Patent search strategies set up for each of the four applications of lipase

\begin{tabular}{|c|c|}
\hline Lipase application & Search strategy \\
\hline Kinetic resolution & $\begin{array}{l}\text { ((((LIPASE?)/BI AND (ENANTIO+ OR STEREO_SELECTIV+ OR (OPTIC+ W } \\
\text { (ACTIV+ OR PUR+ OR ISOMER+)) OR RESOLUTION OR ((SPLIT+ OR } \\
\text { SEPARAT+ OR RESOLV+ OR ESTERIF+) S (CHIRAL+ OR RACEM+ )))/ } \\
\text { BI AND (C12P OR CO7C OR CO7D OR C12R OR C12N)/IC) NOT (LIPASE S } \\
\text { (INHIBITOR+ OR MODULAT+ OR DEFICIENCY))/BI)) AND (EPRD = 1983- } \\
01-01: 2012-12-31)\end{array}$ \\
\hline Production of detergents & $\begin{array}{l}(((\text { LIPASE?)/BI AND (DETERGENT? OR + WASH+ OR LAUND+ OR } \\
\text { BLEACH+ OR CLEAN+ OR SOAP+)/BI) AND (C11D OR C12N)/IC) AND } \\
(\text { (EPRD = 1983-01-01:2012-12-31) }\end{array}$ \\
\hline $\begin{array}{l}\text { Production of food and } \\
\text { feed products }\end{array}$ & $\begin{array}{l}\text { ((((LIPASE?)/BI AND (FOOD+ OR FEED+ OR JUICE OR BEVERAGE+ OR } \\
\text { FISH OR DOUGH OR MILK+ OR CHEESE+ OR BUTTER+ OR MEAT OR } \\
\text { EGG OR YOLK OR BREAD))/BI) NOT ((INHIBITOR+) S LIPASE/BI)) AND } \\
\text { (A23+ OR A21+ OR C12N)/IPC AND (EPRD = 1983-01-01:2012-12-31) }\end{array}$ \\
\hline Production of biodiesel & $\begin{array}{c}\text { (((LIPASE?)/BI AND ((+FUEL? OR + DIESEL?) OR (FATTY ACID W (METHYL } \\
\text { OR ALKYL) W ESTER?) OR FAME OR FAAE)/BI) AND (C12P OR C10L OR } \\
\text { C12N OR C11C OR C10G)/IC) AND (EPRD = 1983-01-01:2012-12-31) }\end{array}$ \\
\hline
\end{tabular}

"?" is a truncation symbol replacing zero or one character; " + " is a truncation symbol representing any number of characters; "_ is an operator indicating that two terms may be connected in a single word or separated in two adjacent words; "W" is an operator indicating that the adjacent terms are in the order specified; " $\mathrm{S}$ " is an operator indicating that the terms are in the same sequence. /BI: the terms were searched in the title and abstract of the patent documents; /IC: international patent classification; EPRD: first priority date of the patent family

Table 3 Publication search strategies set up for each of the four applications of lipase

\begin{tabular}{ll}
\hline Lipase application & Search strategy \\
\hline Kinetic resolution & TITLE:(LIPASE\$) AND TOPIC((KINETIC OR CHIRAL OR LIPASE OR HYDROLY- \\
& SIS OR ENZYMATIC) NEAR/1 RESOLUTION) AND PUBLICATION \\
& YEARS:(1983-2012) \\
TITLE:(LIPASE\$) AND TOPIC(*DETERGENT\$ OR LAUNDR* OR DISH* & OR (REMOV* OR CLEAN* OR WASH*) NEAR/1 (STAIN* OR OIL\$ OR \\
Groduction of detergents & GREASE OR FAT* OR TRIGLYCERIDE\$ OR SOIL\$))) AND PUBLICATION \\
& YEARS:(1983-2012) \\
Production of food and feed products & TOPIC:(LIPASE* AND (((FOOD* OR FEED) NEAR/5 (INDUSTR* OR FORMU- \\
& LATION* OR PRODUCT*)) OR (CHEESE* NEAR/1 (RIPENING OR FLAVOR* \\
& OR MAKING OR PRODUCT*)) OR ((BUTTER OR MILK) NEAR/O (EQUIVA- \\
& LENT* OR SUBSTITUTE*)) OR“DAIRY PRODUCT*" OR DOUGH*)) AND \\
& PUBLICATION YEARS: (1983-2012) \\
Production of biodiesel & TITLE:(LIPASE\$) AND TOPIC(BIODIESEL OR DIESEL OR BIOFUEL\$ OR FUEL\$) \\
& AND PUBLICATION YEARS: (1983-2012)
\end{tabular}

"**" is a truncation symbol replacing any number of characters; " $\$$ " is a truncation symbol replacing zero or one character; "NEAR/ $\mathrm{n}$ " is an operator indicating that two terms are within $n$ words of each other

Such difference between imports and exports is more significant when the analysis is performed considering the value of the goods (Fig. 1a). This is so since Brazil's exports are mainly characterized by low value-added goods, whilst the country depends on high value-added goods produced abroad.

Another indicative of the low value-added of the goods included in the enzyme technology field exported by Brazil is the comparison between the percentage of exports in USD and tons (Fig. 2). In the period of analysis, the percentages of exports measured by value and volume are of around 14 and $40 \%$ respectively. This fact indicates that Brazil import more added value goods when compared with the exported goods.

Comparing Brazil's biotechnology potential expressed by its great biodiversity found in many biomes (e.g. Amazon Forest, Cerrado, Atlantic Forest, and others) with Brazil's 

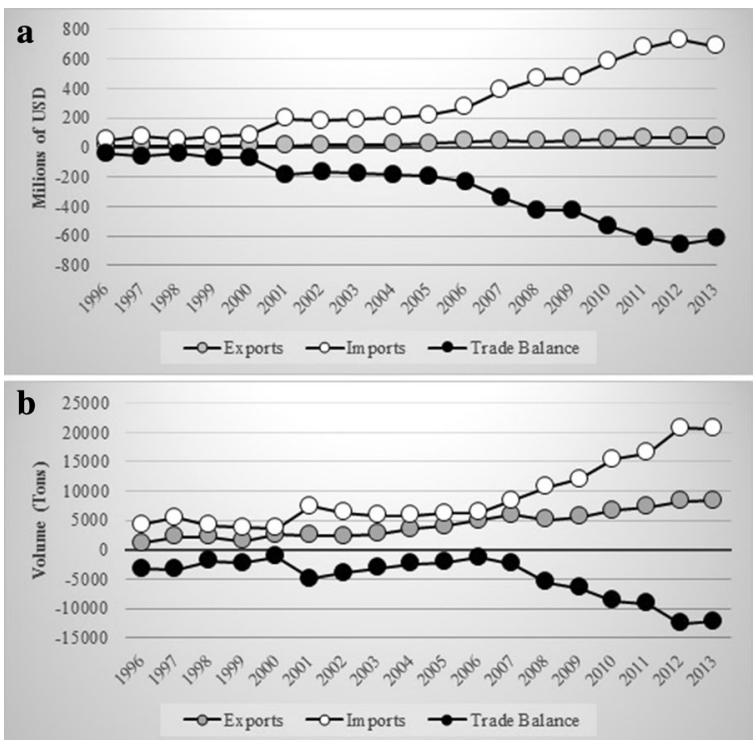

Fig. 1 Exports (gray), imports (white) and trade balance (black) including the thirty-one MCNs; a in terms of values (in millions of USD); and $\mathbf{b}$ in terms of amounts (in tons). The profile of both graphs showed no significant difference when the three doubtful MCN codes were not considered (data not provided)

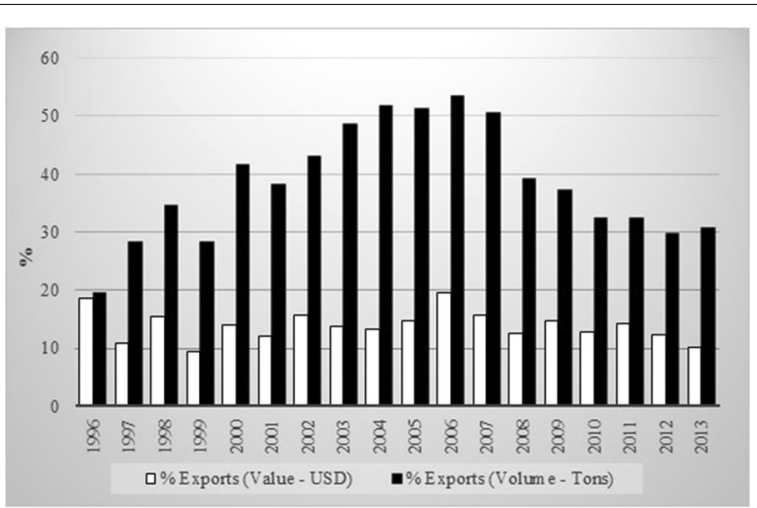

Fig. 2 Exports divided by total trade balance in USD (white) and exports divided by total trade balance in tons (black)

trade balance deficit the contradiction is visible. Why Brazil has one of the most important biodiversity of the world but has a negative trade balance in enzyme market? Could the trade balance deficit be explained by a deficit in technical staff? In order to answer these questions the researcher community in Brazil has been analyzed using data obtained at the National Council for Scientific and Technological Development (CNPq)'s database.

\section{Research community}

According to data provided at CNPq's website, by December 2013 Brazilian postgraduate programs had granted almost 310,000 master's degrees and 172,000 doctoral degrees. In areas related to enzyme technology (chemical engineering, science and food 
technology, biochemistry, microbiology, pharmacy and chemistry), these numbers are 14,285 and 17,660, respectively, corresponding to 5 and $10 \%$ of the total (Figs. 3, 4).

Furthermore, Brazil's participation in the global scientific production remarkably grew over the last 20 years. In 2009, Brazil occupied the 13th place in the international ranking of scientific publications, surpassing countries such as Belgium and Denmark, which have more experience and tradition in the development of science (Almeida and Guimarães 2013). According to Almeida, the current performance of the country in producing science may be directly related to the expansion of the postgraduate system, which has been growing at a rate of $10 \%$ per year in terms of new courses and number of master's and doctoral degree holders.

By analyzing such data, it can be verified that Brazil has significant numbers concerning the technical staff in enzyme technology correlated areas. Nevertheless, when considering the scientific production in enzyme technology by searching for accurate phrases associated to this field in researchers' online curriculum, it can be observed that the numbers are lower than it could have been expected from the previous data. Although $10 \%$ of the doctoral degree holders are included in areas related to enzyme
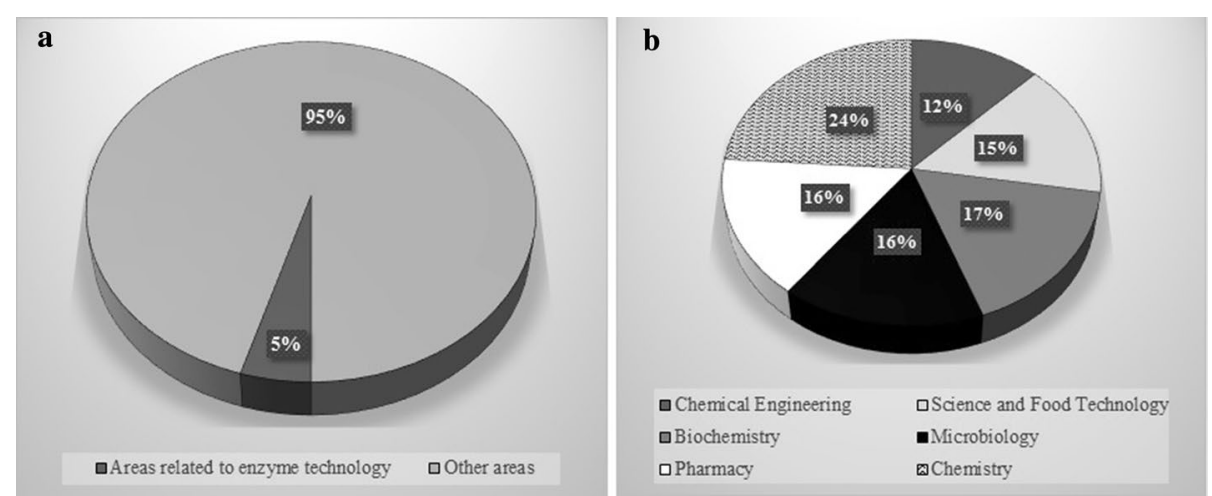

Fig. 3 a Percentage of master's degrees granted by Brazilian postgraduate programs in areas related to enzyme technology, $\mathbf{b}$ percentage distribution per area of the master's degrees granted in areas related to enzyme technology

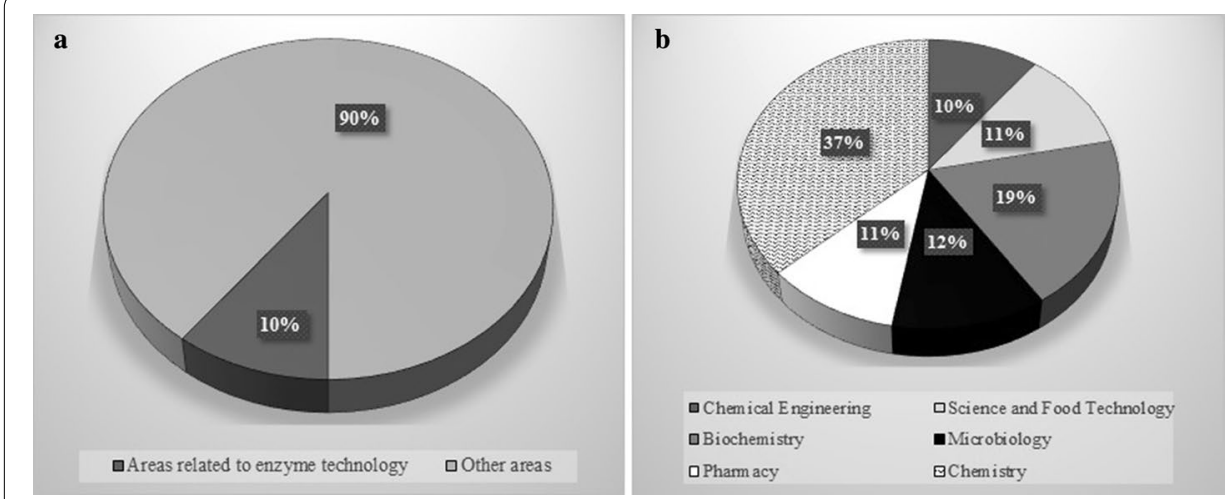

Fig. 4 a Percentage of doctoral degrees granted by Brazilian postgraduate programs in areas related to enzyme technology, $\mathbf{b}$ percentage distribution per area of the doctoral degrees granted in areas related to enzyme technology 
technology, a much smaller percentage is indeed producing knowledge in areas such as "enzyme technology", "enzyme production", "enzyme immobilization" and "enzymology" (Table 4).

\section{Research community specialization}

Table 5 shows a correlation of the MCN codes, each represented by a keyword, with the scientific production of Brazilian researchers in the enzyme technology field. The results of the search for "production of (keyword)" in the researchers' online curriculum render clear the dominance of the Brazilian research on the so-called "enzyme commodities", that is, large scale produced enzymes with low marked prices. Xylanase, amylase, protease, cellulase and lipase are enzymes that may be characterized as enzyme commodities. As commodities, these enzymes are used in detergents composition, food industry, bioenergy production (ethanol 2G and biodiesel), etc. Although it cannot be asserted that all researchers listed in Table 5 works in the areas they have been allotted, it is interesting to observe that there is a correlation between the Brazilian economic structure, which is based on the production of commodities and low value-added goods, and the kind of enzymes most studied by the Brazilian researcher community. These data may suggest that economic specialization promotes a parallel specialization in the enzyme technology research community.

\section{Bibliometric study}

In order to access information regarding the type of work that has been realized by such scientific community, a bibliometric study related to scientific publications and patent documents was performed. Four industrial sectors that employ lipases were took into consideration-kinetic resolution, production of food and feed, detergent and biodiesel. Lipases were chosen as the enzyme model as they are one of the enzyme groups most researched by the Brazilian scientific community (Table 5 ).

Although the Brazilian contribution to the global scientific production is of $2.4 \%$, Brazil accounts for only $0.2 \%$ of the filings of patent applications, which is considered an important technical indicator (Em discussão! Revista de Audiências Públicas do Senado Federal 2012). As to enzyme technology, more specifically to lipases, the results of the present bibliometric study show that the Brazilian participation in the development and publication of scientific and patent follows the same pattern (Fig. 5).

In kinetic resolution, Brazil is in the eleventh position in the ranking of scientific publications, totaling 52 documents between 1983 and 2012; in the triennium of from 2010

Table 4 Accurate phrases related to the enzyme technology field searched in the online curriculum of the researches

\begin{tabular}{llc}
\hline Accurate phrases & DScs & Other researchers \\
\hline Enzyme technology & 108 & 38 \\
Enzyme production & 566 & 481 \\
Enzyme immobilization & 206 & 65 \\
Enzymology & 345 & 143 \\
Enzyme kinetics & 276 & 93
\end{tabular}

"Other researches" includes MSc, graduate and undergraduate students, and others 
Table 5 Correlation of the MCN codes with the scientific production of Brazilian researchers

\begin{tabular}{|c|c|c|}
\hline MCN & Keyword & $\begin{array}{l}\text { Number of DSc + Other researchers } \\
\text { "Production of (keyword)" }\end{array}$ \\
\hline 23099060 & Xylanase & 200 \\
\hline 30021033 & Urokinase & 0 \\
\hline 35071000 & Rennet & 9 \\
\hline 30039021 & Streptokinase & 0 \\
\hline \multicolumn{3}{|l|}{30049011} \\
\hline \multicolumn{3}{|l|}{35079023} \\
\hline 35079024 & Streptodornase & 0 \\
\hline \multirow[t]{2}{*}{35079025} & Streptodornase & 0 \\
\hline & Streptokinase & 0 \\
\hline 30039023 & Deoxyribonuclease & 2 \\
\hline \multicolumn{3}{|l|}{30049013} \\
\hline 35079032 & Asparaginase & 28 \\
\hline \multicolumn{3}{|l|}{30049012} \\
\hline 35079011 & Alfa-amylase & 76 \\
\hline 35079019 & Amylase & 149 \\
\hline 35079021 & Fibrinolysin & 0 \\
\hline 35079022 & Bromelain & 4 \\
\hline 35079026 & Papain & 2 \\
\hline 35079029 & Protease & 167 \\
\hline 35079031 & Lysozyme & 1 \\
\hline 35079041 & Cellulase & 194 \\
\hline \multirow[t]{2}{*}{30021032} & Plasmin & 0 \\
\hline & Fibrinolysin & 0 \\
\hline 35079042 & Transglutaminase & 14 \\
\hline \multirow[t]{2}{*}{35079049} & Protease & 167 \\
\hline & Collagenase & 13 \\
\hline \multirow[t]{4}{*}{30039029} & Pancreatin & 0 \\
\hline & Lipase & 371 \\
\hline & Protease & 167 \\
\hline & Amylase & 149 \\
\hline \multirow[t]{5}{*}{35079039} & Glucose oxidase & 2 \\
\hline & Catalase & 8 \\
\hline & Cellulase & 194 \\
\hline & Pectinase & 50 \\
\hline & Lipase & 371 \\
\hline
\end{tabular}

to 2012 Brazil occupied the second position in such ranking, only behind China. Nevertheless, Brazilian participation in the filing of patent applications is not as significant. No patent document found in the searches claims priority for a Brazilian document.

In production of food \& feed, industrial sector that demands the greatest amount of enzymes in Brazil, 29 \% in 2012 (Freedonia Group 2014), only one patent document claiming priority for a Brazilian document was found, which was filed by the Federal University of Minas Gerais and the company Phoneutria Biotecnologia e Serviços Ltda. On the other hand, Brazil ranks fifth in number of scientific documents published in this sector from 1983 to 2012, with 16 publications. 


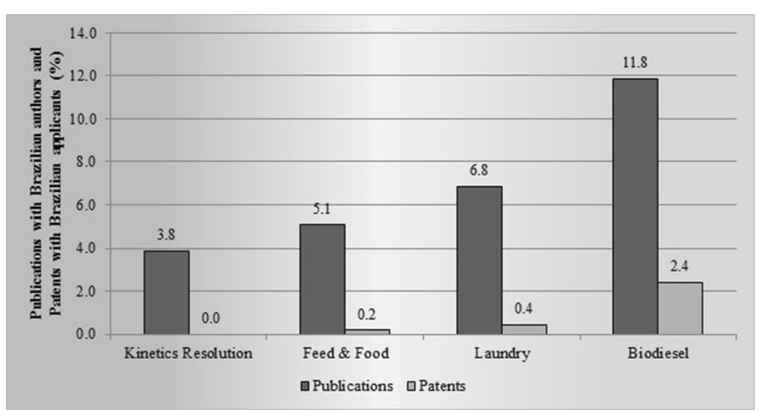

Fig. 5 Percentage of scientific publications with Brazilian authors and patents with Brazilian applicants Bibliometric studies realized from 1983 to 2012

Brazil is the fourth largest global market of cleaning products, and in 2012 had revenues of 14.9 billion reais (ABIPLA 2013). In the searches for scientific documents published by Brazilian research groups, only eight articles were detected in the period from 1983 and 2012, five of which are authored by groups from the State University of Campinas-UNICAMP). Moreover, despite the growing importance of the Brazilian market, only two patent documents have national applicants in the same period, one of them being co-assigned with Unilever N.V.

The Brazilian global participation as biodiesel consumer and producer is significant. In 2013, the country was the second largest consumer of such biofuel, with a demand of 2.9 million $\mathrm{m}^{3}$. In the same year, the country ranks third in the production of biodiesel, yielding 3.0 million $\mathrm{m}^{3}$ (Ministério de Minas e Energia 2014). Brazil also stands out in studies related to biofuels. With specific respect to the scientific research related to the use of lipases for biodiesel production by enzymatic route, the country occupied the second global position up to 2012, with 52 publications. However, despite the country's expressiveness in scientific publications directed to biodiesel production by transesterification involving lipases, only five patent documents, among the 165 documents found in the search, were filed by Brazilian applicants. It is noteworthy that the participation of Brazilian public universities in the filing of patent documents is more expressive than that of Brazilian companies.

The analysis of the publication countries of a given patent document can be used as an indication of the attractiveness of a country to foreign technologies. The results of the searches show that Brazil is not one of the most attractive countries to external technologies related to the industrial use of lipases (Fig. 6), the highest values being found in the detergent sector, wherein the country occupies the eighth position with almost $20 \%$ of the patents published in Brazil. Conversely, in the other sectors included in this study-kinetic resolution (nineteenth position), food and feed (thirteenth position) and biodiesel (ninth position)-Brazil is behind countries that have lower performance in scientific publication in the same sectors. In the case of kinetic resolution, for example, Brazil is behind countries like South Africa and Hungary.

Taking all data together, it can be assumed that the deficit in the Brazilian trade balance of enzyme-related goods is not entirely due to a lack of technical staff, since a considerable number of DSc and MSc are formed every year in areas related to enzyme technology. However, taking into account the bibliometric study carried out, and 


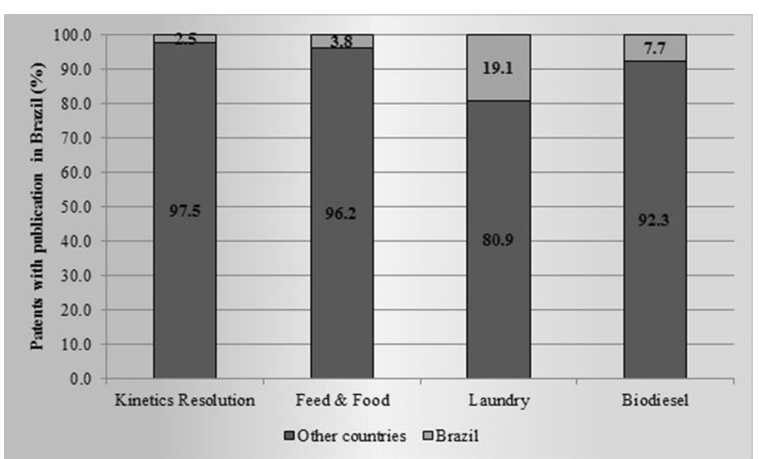

Fig. 6 Percentage of patents with publication in Brazil in comparison with all other countries. Bibliometric studies realized from 1983 to 2012

considering that the Brazilian contribution in the filing of patent documents is only marginal, it can be assumed that theses researchers have not been producing knowledge inside the productive sector (i.e. industries), but mainly in universities and governmental research centers. These results may be explained by the fact that only $42 \%$ of the Brazilian researches are employed in firms, while $79 \%$ of North American researchers leave the university (Em discussão! Revista de Audiências Públicas do Senado Federal 2012). These findings can be related to the type of industrial production performed in Brazil, which is specialized in producing low-value added products, and to the low public and private investments in scientific researches.

In fact, an expanded look shows that trade deficit reaches the Brazilian trade balance as a whole, and is even greater for goods of the manufacturing industry (Instituto de Estudos para o Desenvolvimento Industrial 2014). Considering the classification according to technological intensity used by the Organization of Economic Co-operation and Development (OECD), it can be observed that Brazil is specialized in exporting low technological goods. On the other hand, Brazil's imports are mainly constituted by goods with media-high and high technological intensity (Fig. 7). While imports of medium-high and high technological intensity goods totalize around $60 \%$ of Brazilian overall trade balance, exports of this group of goods account only for $25-30 \%$. These numbers suggest a specialization in Brazilian industrial policy in favor of producing low value-added goods.

\section{Brazilian Industrial Policy related to biotechnology}

Although the development of the biotechnological field has been a priority of the Brazilian government since 1970 (Ferrer et al. 2004), it seems that the different programs created ever since have not been effective in transforming the country into a reference in industrial biotechnology. It is only from 2004, with the Industrial and Technological and Foreign Trade Policy, that biotechnology has been considered as a "strategic field" (Bianchi 2013).

In 2007, the Brazilian government launched the Biotechnology Development Policy (Decree No. 6041), which, according to its first article, "aims to establish a suitable environment for the development of innovative biotechnology products and processes". It 


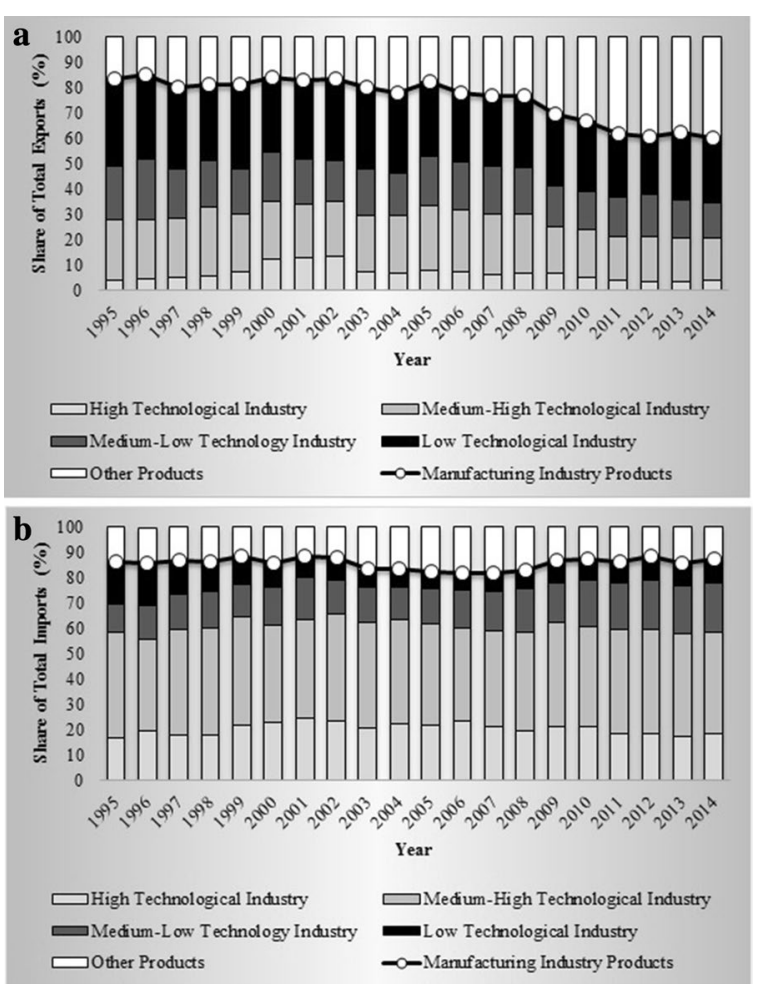

Fig. 7 a Exports of products of the Manufacturing Industry by technological intensity and further products; and $\mathbf{b}$ imports of products of the Manufacturing Industry by technological intensity and further products Source: Letter IEDI n. 622, 2014

has also created the Biotechnology National Committee, responsible for coordinating the implementation of the Biotechnology Development Policy.

The industrial policy currently in force is the Greater Brazil Plan, launched in 2011. In a document published in 2013 by the National Confederation of Industry called "Bioeconomy: an agenda for Brazil", it is proposed the inclusion of biotechnology in the "Structuring Guideline 2-Expansion and creation of new technological and business skills". Such inclusion would allow that all measures being taken in other sectors to boost investments were extended to biotechnology (Harvard Business Review Analytic Services 2013).

Despite all these policies, the biotech sector in Brazil is yet weak, as it has been shown in 2011 by the Brazilian Biotechnology Association. The Brazil Biotech Map-2011 (BRBiotec 2011) is a report about private companies in Brazilian territory. This report has showed that Brazil had 237 biotech companies; most of them being micro and small sized-companies. Among these companies, $56 \%$ have annual revenues of no more than R \$ 2.4 million (around 1.5 million dollars), $20 \%$ have no revenues, and $85 \%$ have up to 50 employees ( $20 \%$ of them between 1 and 5 employees and $25 \%$ of them having between 6 and 10). Furthermore, $25 \%$ of the companies export, but on the other hand, $86 \%$ of them import especially reagents and equipment for the production and development of technology. 


\title{
Conclusion
}

The trade balance of enzyme-related goods in Brazil is negative, and despite the Brazilian industrial policies and the Biotechnology Development Policy created in 2007, it has a tendency to become even more negative. The data presented herein suggests that Brazil has a sufficient technical staff. However, it does not means that the community research in enzyme technology is saturated. The major problem seems to be that the increase in the number of scientists is not accompanied by a proportional increase in the indicators of innovation in the country, which can also be observed in the bibliometric studies involving lipases, the most studied group of enzymes in Brazil. One other possible explanation for such disparity is the lack of demand by the Brazilian private firms.

On the other hand, when the entire Brazilian trade balance is analyzed, it is possible to conclude that the majority of Brazilian exports are composed of non-industrial or lowtechnological goods. The loss of national industrial competitiveness is another result of the lack of innovation, which will not be overcome if additional public and private investments are not made in science and technology.

\section{Authors' contributions}

RVA conceived of the study, and participated in its design and coordination and helped to draft the manuscript; KGD participated in the design of the manuscript and drafted it; GCB, ALL and DMGF critically revised the manuscript for important intellectual content. All authors read and approved the final manuscript.

\begin{abstract}
Author details
1 Laboratório de Microbiologia Molecular e Proteínas, Instituto de Química, Universidade Federal do Rio de Janeiro, Ave Athos da Silveira Ramos, 149, Ilha da Cidade Universitária, Centro de Tecnologia, Block A, Room 541, Rio de Janeiro 21941-909, Brazil. ${ }^{2}$ Centro de Estudos da Saúde do Trabalhador e Ecologia Humana, Escola Nacional de Saúde Pública Sergio Arouca - Fundação Oswaldo Cruz, St Leopoldo Bulhões, 1480, Manguinhos, Rio de Janeiro 21041-210, Brazil. ${ }^{3}$ Laboratório de Biotecnologia Microbiana, Instituto de Química, Universidade Federal do Rio de Janeiro, Ave Athos da Silveira Ramos, 149, Ilha da Cidade Universitária, Centro de Tecnologia, Block A, Room 549a, Rio de Janeiro 21941-909, Brazil.
\end{abstract}

\section{Acknowledgements}

We would like to thank FAPERJ, CAPES, CNPq and PETROBRAS for their financial support and Banco Central do Brasil for providing the numbers of trade balance.

\section{Competing interests}

The authors declare that they have no competing interests.

Received: 4 February 2016 Accepted: 2 May 2016

Published online: 11 May 2016

\section{References}

Almeida ECE, Guimarães JA (2013) Brazil's growing production of scientific articles-how are we doing with review articles and other qualitative indicators? Scientometrics 97:287-315

Associação Brasileira das Indústrias de Produtos de Limpeza e Afins (2013) Anuário 8a edição. Available via DIALOG. http://www.abipla.org.br/novo/arquivoanuario/arq36.pdf. Accessed 27 Jan 2015

Bianchi C (2013) A indústria brasileira de biotecnologia: montando o quebra-cabeça. Rev Econ Tecnol 92:99-116 BRBiotec Brazil (2011) Brazil biotech map. Available via DIALOG. http://www.cebrap.org.br/v1/upload/pdf/Brazil_Biotec_Map_2011.pdf. Accessed 15 Jan 2016

Buchholz K, Kasche V, Bornscheuer UT (2012) Biocatalysts and Enzyme Technology, 2nd edn. Wiley-Blackwell, London

Centre for Economics and Business Research (2013) World economic league table. Available via DIALOG. http://www. telegraaf.nl/incoming/article22168758.ece/BINARY/+Cebr_World-Economic-League-Table-2013.pdf. Accessed 15 Jan 2016

Daiha KG, Angeli R, de Oliveira SD, Almeida RV (2015) Are lipases still important biocatalysts?A study of scientific publications and patents for technological forecasting. PloS One. doi:10.1371/journal.pone.0131624

Ferrer M, Thorsteinsdóttir H, Quach U, Singer PA, Daar AS (2004) The scientific muscle of Brazil's health biotechnology. doi:10.1038/nbt1204supp-DC8

Freedonia Group (2014) World enzymes_-demand and sales forecasts, market share, market size, market leaders. http:// www.freedoniagroup.com/World-Enzymes.html. Accessed 15 Jan 2016 
Harvard Business Review Analytic Services (2013) Bioeconomia: uma agenda para o Brasil. Available via DIALOG. http:// arquivos.portaldaindustria.com.br/app/conteudo_24/2013/10/11/410/20131011094912801299u.pdf. Accessed 15 Jan 2016

Instituto de Estudos para o Desenvolvimento Industrial (2014) A deterioração persistente da balança comercial brasileira. Available via DIALOG. http://www.iedi.org.br/cartas/carta_iedi_n_622.html. Accessed 15 Jan 2016

Ministério de Minas e Energia (2014) Boletim mensal dos combustíveis renováveis. Available via DIALOG. http://www biomercado.com.br/imagens/publicacao/arquivo94.pdf. Accessed 03 Feb 2015

Mittermeier RA, Gil RP, Hoffman M, Pilgrim J, Brooks T, Mittermeier CG, Lamoreux J, Fonseca GAB (eds) (2005) Hotspots revisited: earth's biologically richest and most endangered terrestrial ecoregions. University of Chicago Press, Boston Nature Editorial (2010) Brazil's biotech boom. Nature. doi:10.1038/466295a

Resende V (2012) The biotechnology market in Brazil. Available via DIALOG. http://www.nccommerce.com/Portals/5/ Documents/ITD/Biotech\%20Market\%20in\%20Brazil.pdf. Accessed 15 Jan 2016

Em discussão! Revista de Audiências Públicas do Senado Federal (2012) Inovação: País contrói pontes entre ciência e indústria. Em discussão! Revista de Audiências Públicas do Senado Federal 3(12):1-72

United Nations Population Found (2010) From conflict and crisis to renewal: generation of change. State of the world population. Available via DIALOG. http://www.unfpa.org/webdav/site/global/shared/documents/publications/2010/EN_SOWP10.pdf. Accessed 15 Jan 2016

\section{Submit your manuscript to a SpringerOpen ${ }^{\circ}$ journal and benefit from:}

- Convenient online submission

\section{- Rigorous peer review}

- Immediate publication on acceptance

Open access: articles freely available online

- High visibility within the field

- Retaining the copyright to your article

Submit your next manuscript at $\boldsymbol{\nabla}$ springeropen.com 